\title{
THE BRYOFLORISTIC ELEMENTS OF SOUTHERN AFRICA
}

\author{
JACQUES VAN ROOY'12 and ABRAHAM E. VAN WYK ${ }^{1}$ \\ ${ }^{1}$ University of Pretoria and ${ }^{2}$ South African National Biodiversity Institute, Pretoria, South \\ Africa
}

\section{SUMMARY}

A TWINSPAN classification divides the moss flora of southern Africa (South Africa, Namibia, Botswana, Swaziland and Lesotho) into two main bryofloristic elements: (1) the Xerophytic (south-western) element mainly distributed in the winter rainfall and semi-arid to arid, temperate areas of southern Africa, and (2) the Mesophytic (subtropical) element distributed in more stable, subtropical habitats of the northern, eastern and southern parts of southern Africa. The Xerophytic element is dominated by acrocarpous mosses, including the ephemerals, while the Mesophytic element contains most of the pleurocarpous mosses. The main Xerophytic element is subdivided into the Eastern Highlands and Cape Elements while the Mesophytic element consists of the Afromontane Grassland and Afromontane Forest Elements. The Afromontane Forest Element is the largest bryofloristic element and contains the most southern African moss endemics. The four bryofloristic elements are subdivided into eight subelements: the Eastern Highlands Element into the Mont Aux Sources and Widespread Subelements, the Cape Element into the West Coast and Boland Subelements, the Afromontane Grassland Element into the Disjunct Cape Peninsula and Drakensberg Subelements, and the Afromontane 
Forest Element into the Widespread Afromontane and Tropical Afromontane Subelements. Many of the bryofloristic elements and distribution centres correspond with phytogeographical elements and centres described for the seed plants of southern Africa. The Afromontane area in the south-western Cape is identified as a bryogeographical hotspot.

KEYWORDS: Distribution patterns, floristic elements, moss flora, numerical classification, TWINSPAN, plant biogeography, southern Africa.

\section{INTRODUCTION}

A floristic element consists of plant taxa (e.g. species) of similar geographical distribution (van Rooy \& van Wyk, 2010 and references therein). The distribution ranges of floristic elements may overlap, but a species can only belong to one floristic element. Concentrations of species (or higher taxa) within the distribution areas of floristic elements are known as centres, subdivided into subcentres.

In southern Africa (Fig. S1), floristic elements have generally been described in certain plant groups only (e.g. Levyns, 1954; Nordenstam, 1969; Acocks, 1971; Kurzweil, Linder \& Chesselet, 1991; Hilliard, 1994), in floras of restricted geographical areas (e.g. Weimarck 1941, Cowling 1983; Hilliard \& Burtt 1987; Linder, Meadows \& Cowling, 1992; Carbutt \& Edwards, 2006), or a combination of the two (e.g. Russell \& van Rooy, 1988a, 1988b; Geldenhuys, 1994; Hodgetts, Matcham \& Duckett, 1999). An exception is the global distributional elements described for families and genera in the seed plant flora of the entire Flora of southern Africa (FSA) region by Goldblatt (1978). 
The main objective of this paper is to delimit and describe floristic elements in the moss flora of southern Africa by means of a repeatable, numerical technique. Another important objective is to compare the bryofloristic elements with floristic elements described for seed plants of the region. The relationships between the bryofloristic elements and the bryofloristic regions described by van Rooy \& van Wyk (2010), as well as the biomes of Rutherford \& Westfall (1986), are also discussed.

\section{MATERIALS AND METHODS}

The study area (Fig. S1), data collection, data sets and data analysis have been described in detail by van Rooy (2000) and van Rooy \& van Wyk (2010). Taxonomy and nomenclature follow van Rooy (2000, 2003).

The moss flora of southern Africa consists of 503 species/infraspecific taxa (species) in 204 genera and 54 families (Appendix S1). This represents about 5\% of the world's mosses and $17 \%$ of mosses in Africa (O'Shea, 1997). The Pottiaceae is by far the largest moss family in southern Africa, followed by Dicranaceae and Bryaceae. Fissidens is the largest moss genus while the second place is shared by Bryum and Campylopus. One family (Wardiaceae), six genera (Cygnicollum, Microcrossidium, Physcomitrellopsis, Ptychomitriopsis, Quathlamba and Wardia), and 114 species (23\% of the total moss flora), are listed as endemic to southern Africa by van Rooy (2000). Since the completion of the numerical analysis, the following endemic genera (all Pottiaceae) have been described from the south-western Cape: Acaulonopsis, Algaria, Ludorugbya and Vrolijkheidia (Hedderson \& Zander, 2007, 2008a, 2008b; Zander \& Hedderson, 2009). 
The classification of bryofloristic elements within the FSA region is hierarchical and based exclusively on the results of the TWINSPAN 3+ analysis (see van Rooy \& van Wyk, 2010). Because of the regional nature of this study the names of the two main elements are provisional.

The relationship between the bryofloristic elements and the bryofloristic regions of van Rooy \& van Wyk (2010) was studied by summarising the re-ordered TWINSPAN 3+ datamatrix in a two-way table (Fig. 15). The abundance of each subelement in each domain (represented by different sized dots in the figure) was estimated as follows: The total number of species in a particular subelement was multiplied by the total number of grids in a specific domain. The actual number of occurrences of the subelement in the domain was then counted and the percentage calculated. The percentages were then grouped into 10 classes represented by different-sized dots in the table.

\section{RESULTS}

The first and major TWINSPAN 3+ division splits the moss species into two large groups or elements (Fig. S2). Element 1/1 (first level of division, group one) is the smallest of the two main elements with 131 species while the larger element 1/2 consists of 370 species. At the second level of division the two main elements are subdivided into two groups each (2/1-2/4). These four elements are further subdivided into two groups each to form a total of eight groups at the 3rd level of division ( $3 / 2-3 / 8)$.

TWINSPAN goes on to subdivide the moss flora into 16 elements at the 4th, 30 elements at the 5th, and 50 elements at the 6th and last level of division. Although at least some of these 
elements are ecologically meaningful, only the elements at the first three levels, or the macroregional scale, are described below.

The floristic composition of each element is given in Appendix S1. The number of taxa, largest families and genera, as well as the percentage FSA endemics in each of the bryofloristic elements and subelements are listed in Appendix S2.

\section{THE TWO MAIN BRYOFLORISTIC ELEMENTS}

Xerophytic (south-western) element (1/1)

The species. Consists mostly of acrocarpous taxa in the Orders Dicranales, Pottiales, Funariales, Bryales and Orthotrichales (see Appendix S1) of which the Pottiales is particularly well represented. The families Encalyptaceae, Bryobartramiaceae, Grimmiaceae and the endemic family Wardiaceae are restricted to this group. Most of the taxa in this element are xerophytic and therefore adapted to life in the semi-arid to arid conditions of the main distribution area. Most of the ephemerals (see van Rooy, 2000) belong to this element: six species of Archidium, four of Pleuridium, Aloina bifrons, Acaulon recurvatum, A. leucochaete, Crossidium spiralifolium, Microcrossidium apiculatum, Pottia namaquensis, Bryobartramia novaevalesiae, Chamaebryum pottioides, Gigaspermum repens, Ephemerum namaquense, E. rehmannii, Cygnicollum immersum, and Goniomitrium africanum. Pleurocarpous mosses of the Order Hookeriales are absent from this element and the Orders Isobryales, Thuidiales and Hypnobryales are poorly represented. 
Geographical distribution. The xerophytic element is mainly distributed in the southwestern, winter-rainfall part of the study area as well as the high altitude, temperate areas of the interior plateau (Fig. 1). The two main centres of distribution (named after Stuckenberg, 1962) are:

1. Cape Centre: The main distribution centre of this element is located in the south-western Cape Fold Mountains, in particular the Table mountain grid (3318 C), Stellenbosch (3318 D), the Boland (3319 C) and the Cedarberge at Clanwilliam (3218 B).

2. Eastern Highlands Centre: Consists of the high plateau of Lesotho, in particular the Mont Aux Sources - Oxbow area (2828 D).

Other areas with relatively high species concentrations are: (1) the Bokkeveldberge at Niewoudtville (3319 A), (2) the mountains at Springbok (2917 D), (3) the mountains of the Richtersveld, in particular grid 2927 A, (4) the highlands at Windhoek in Namibia (2217 B), (5) the Outeniqua Mountains between George and Oudsthoorn (3322 A \& C), (6) the mountains around Graaff Reinet (3224 A \& B, 3124 D) and Middelburg (3024 B, 3025 C) and further north to Reddersburg in the southern Free State (2926 A), congruent with the distribution area of the Sneeuwbergen Group and Centre of Nordenstam (1969) and Hilliard (1994), and (7) the Witteberge in the Zastron-Lady Grey area (3027 A \& C).

Mesophytic (subtropical) element (1/2)

The species. The pleurocarpous Orders Isobryales, Hookeriales, Thuidiales and Hypnobryales are restricted or largely restricted to this element (Appendix S1). Acrocarpous taxa adapted to subtropical forest/woodland environments, such as Leucobryum, Calymperes, Syrrhopodon and 
Rhodobryum, are also restricted to this element. Many of the xerophytic Orthotrichaceae, adapted to habitats on trees and rocks within the Afromontane forest areas (e.g. Macrocoma, Macromitrium and Schlotheimia species) also form part of this element. The following families, mostly pleurocarpous, are restricted to (have all their southern African representatives confined to) the main subtropical, mesophytic element: Seligeriaceae, Splachnaceae, Mniaceae, Eustichiaceae, Erpodiaceae, Rhachitheciaceae, Rhabdoweisiaceae, Racopilaceae, Fontinalaceae, Cryphaeaceae, Leucodontaceae, Prionodontaceae, Trachypodaceae, Pterobryaceae, Meteoriaceae, Leptodontaceae, Neckeraceae, Thamnobryaceae, Hookeriaceae, Stereophyllaceae, Leskeaceae, Thuidiaceae, Rigodiaceae, Amblystegiaceae, Brachytheciaceae, Entodontaceae, Plagiotheciaceae, Catagoniaceae and Sematophyllaceae.

Geographical distribution. Element $1 / 2$ is widely distributed in the northern, eastern and southern, subtropical (mesic) or Afromontane areas of southern Africa (Fig. 2). The main centres of distribution are:

1. Mpumalanga Centre. The Drakensberg escarpment in the Graskop - Blyderivierspoort (2430 D) and Nelspruit - Sabie (2530 B) areas.

2. KwaZulu-Natal Centre. Situated in the KwaZulu-Natal Drakensberg and Midlands, in particular the montane forests in the Pietermaritzburg - Karkloof area (2930 C and 2930 A) and the High Berg, from Mont Aux Sources in the north to Sehlabathebe in the south (2828 D, 2829 C, and 2929 A \& C). This centre may therefore be subdivided into the Drakensberg and Midlands Subcentres.

Other areas of relatively high species concentrations include: (1) The entire escarpment of the northern provinces, from the Soutpansberg in the north (2230 C) to Swaziland in the south (2631 A), (2) the Magaliesberg, from Pretoria in the east (2528 C) to Rustenburg in the west 
(2527 C), (3) montane forests in the Eshowe - Empangeni area (2831 C and $2831 \mathrm{D}),(4)$

montane forests in the King William's Town area (3227 C), (5) the Knysna and Tsitsikamma forests, especially in the Outeniqua Mountains at George (3322 C), and (6) the Afromontane forest on the eastern slopes of Table Mountain (3318 C ), which is the main secondary centre of distribution.

\section{BRYOFLORISTIC ELEMENTS AND SUBELEMENTS}

Eastern Highlands Element (2/1)

This element, which consists mostly of acrocarpous species in the Orders Dicranales, Pottiales, Funariales, Bryales and Orthotrichales, is mainly distributed on the high altitude plateau of Lesotho and adjacent grassland areas (Fig. 3), extending as far south as the Sneeuberge near Graaff Reinet (3224 B). The centre of distribution is situated the Mont Aux Sources-Oxbow area (2828 D). where 29 of the 47 species occur. Other areas of interest include the KwaZulu-Natal Midlands, Mpumalanga escarpment, Magaliesberg, the Amathole Mountains near King William's Town and the mountains of the south-western Cape.

The distribution ranges of the species vary from those that are nearly restricted to the centre (e.g. Anomobryum drakensbergense, Ptychomitrium diexaratum, Orthotrichum oreophilum) to more widespread species reaching the northern as well as the Cape provinces (e.g. Funaria rottleri, Bartramia hampeana, Ptychomitrium cucullatifolium). The wide distribution of this element is only achieved through the inclusion of a few very widespread 
species, viz. Funaria hygrometrica, Bryum argenteum, B. pycnophyllum and Trichostomum brachydontium.

Mont Aux Sources Subelement (3/1)

The southern African species of Encalyptaceae, a family of montane and arctic mosses (Horton, 1982), are restricted to the Mont Aux Sources Subelement. Funaria, a large and widespread genus, and Didymodon, which is known as 'a cosmopolitan genus widely diversified in temperate and montane regions' (Zander, 1993), are largely restricted to this subelement in southern Africa.

This element, the largest of the Eastern Highlands divisions, is largely restricted to the mountains of north-eastern Lesotho and is named after Mont Aux Sources, one of the highest mountain peaks in grid $2828 \mathrm{D}$, the centre of distribution (Fig. 7). The number of species per grid drops rapidly outside the main distribution area and the relatively wide distribution of the Mont Aux Sources Subelement is only achieved through species such as Fissidens curvatus, Didymodon ceratodonteus, Funaria rottleri, Bryum alpinum and Bartramia hampeana. The endemics Didymodon jackvancei, Weissia dieterleniae, Anomobryum drakensbergense, Ptychomitrium diexaratum and Orthotrichum oreophilum are largely restricted to the main distribution area of the subelement. 
Widespread Subelement (3/2)

This element is more or less evenly distributed throughout the study area (Fig. 8) as a result of frequently collected, widespread species such as Trichostomum brachydontium (Pottiaceae), Schistidium apocarpum (Grimmiaceae), Funaria hygrometrica (Funariaceae) and Bryum argenteum (Bryaceae), all with (sub-)cosmopolitan distributions, as well as Bryum cellulare (pantropical) and Bryum pycnophyllum (east African). The main area of distribution seems to be the KwaZulu-Natal Midlands and Drakensberg foothills, and the mountains of the eastern Free State. The group has its highest diversity around the eastern Free State town of Ficksburg (2827 D).

Other areas of relatively high species diversity are: (1) Port St. Johns on the Wild Coast (3129D), (2) the Ngome forest area near Vryheid in KwaZulu-Natal (2731 C), (3) the Magaliesberg between Pretoria and Rustenburg (2527 D \& 2528 C), (4) the Sabie-GraskopBlyderivierspoort area (2430 D \& 2530 B) as well as the adjacent Sekhukuneland (2430 C), (5) the Malolotja Nature Reserve in northern Swaziland (2631 A), and (6) the Houtbosch and other forests in Limpopo (2329 D).

Cape Element (2/2)

The Cape Element is mainly distributed in the winter rainfall area of the south-western Cape, especially along the north-south axis of the Cape Fold Mountains, from the Cape Peninsula to Namaqualand and the Richtersveld (Fig. 4). Most of the mosses in this element are xerophytic and adapted to the dry, hot summers of the Mediterranean-type climate, analogous to the seed 
plant flora of this area (Goldblatt, 1978). The number of species per grid drops rapidly outside the main distribution area and very few species reach the eastern Cape coast, KwaZulu-Natal, Swaziland, and the northern provinces.

The main centre of distribution is the mountains of the south-western Cape, in particular the Table Mountain (3318 C), Stellenbosch (3318 D) and Boland (3319 C) grids. A secondary centre, probably an extension of the main centre, is situated in the Clanwilliam - Vanrhynsdorp area (3218 B). Species are also concentrated on the escarpment at Springbok (2917 D), the mountains of the Richtersveld (2927 A), the Outeniqua Mountains between George and Oudtshoorn (3322 A \& C), and the southern KwaZulu-Natal Drakensberg (2929 A \& C). Some species, e.g. Bruchia brevipes, Tetrapterum tetragonum, Ptychomitrium crassinervium, Zygodon runcinatus and Orthotrichum incurvomarginatum, are restricted to the main distribution area while others like Fissidens rufescens, Tortula atrovirens, Pseudocrossidium crinitum, Syntrichia ruralis, Grimmia pulvinata and Bryum canariense give this element its wide distribution.

West Coast Subelement (3/3)

The xerophytic West Coast Subelement is the largest of the two Cape subelements and contains most of the ephemerals. Eighty percent of taxa in this element occur in Mediterranean and temperate to hot, semi-arid to arid areas of the world, known as the Xerothermic Pangaean genoelement (Frey, 1990; van Rooy, 2000). Some of these mosses e.g. Fissidens pygmaeus, Acaulon leucochaete, Bruchia brevipes, Bryobartramia novaevalesiae, Gigaspermum repens, Bartramia compacta var. compacta and Ischyrodon lepturus are restricted to areas with a 
Mediterranean type climate, while others e.g. Didymodon australasiae, Pseudocrossidium

crinitum, Syntrichia princeps, Tortula atrovirens, Bryum canariense, Bryum radiculosum, Bryum torquescens and Orthotrichum diaphanum are more widespread and also occur in other climatic regions.

The geographical distribution of the West Coast Subelement is more or less the same as that of the Cape Element. The main distribution area runs parallel to the West Coast, from the Cape Peninsula in the south to the Richtersveld in the north (Fig. 9). The highest numbers of species are found in the Clanwilliam (3218 B) and Cape Town (3318 C) areas with pockets of relatively high species diversity in the Kamiesberge (3018 A) and the northern part of the Richtersveld (2817 A). A number of species range eastward to the Langeberg near Montagu (3320 C) and the Outeniqua Mountains near George (3322 C). The distribution ranges of some species include the high altitude interior plateau but few occur beyond Lesotho.

\section{Boland Subelement (3/4)}

The families Wardiaceae (endemic to FSA) and Aulacomniaceae (southern temperate areas of the world) are restricted to this subelement in southern Africa.

This subelement is largely restricted to the south-western corner of the study area (Fig. 10) and the centre of distribution is Table Mountain (3318 C) and the Cape Fold Mountains of the Boland (3318 D and 3319 C). The number of species per grid drops rapidly outside the main distribution area and very few make it to the northern provinces of South Africa. Up to eight species range as far as the Cedarberge near Clanwilliam, the Groot Swartberge and Outeniqua 
mountain ranges of the Klein Karoo, and the Sani Pass-Sehlabathebe area in the KwaZulu-Natal Drakensberg.

Species more or less restricted to the centre of distribution include Andreaea subulata, Archidium rehmannii, Racomitrium lanuginosum, Pyrrhobryum vallisgratiae, Leptotheca gaudichaudii, Zygodon runcinatus and Wardia hygrometrica, all restricted to Gondwana fragments except Racomitrium lanuginosum with a widespread bipolar distribution. This subelement is only present in the northern provinces of South Africa through the inclusion of Archidium ohioense, Fissidens fasciculatus, Leucoloma sprengelianum and Rhacocarpus purpurascens.

Afromontane Grassland Element (2/3)

The pleurocarpous Orders Isobryales, Hookeriales, Thuidiales and Hypnobryales are poorly represented in, and the Andreales and Polytrichales absent from the Afromontane Grassland Element.

The Afromontane Grassland Element is characterised by three widespread centres of distribution: Table Mountain (3318 C) in the Western Cape, the KwaZulu-Natal Midlands (2930 C) and Drakensberg (2828 D, 2929 A \& C) area, and the Graskop - Blyderivierspoort area (2430 D) in Mpumalanga (Fig. 5). Other areas of relatively high species concentrations include the grids adjacent to the main centres of distribution, the King William's Town (3227 C) and Lady Grey (3027 C) areas in the Eastern Cape, the north-eastern Free State including the Maseru grid (2927 B), and the Magaliesberg between Pretoria and Rustenburg (2527 C \& D, 2528 C). Compared to the Afromontane Forest Element, the number of Afromontane Grassland elements 
in the George - Knysna area of the southern Cape, the Eshowe - Empangeni area in KwaZuluNatal, as well as the Limpopo and Mpumalanga escarpment, is relatively low.

Some species are more or less restricted to the Cape centre of distribution (Trematodon pillansii, Sphagnum pycnocladulum, Calyptrochaeta asplenioides), others only occur in the KwaZulu-Natal centre (Distichium capillaceum, Aongstroemia julacea, Barbula microcalycina, Bryum caespiticium, Pohlia cruda), but none is restricted to the northern or Mpumalanga centre. A number of species occur in all three centres, of which Fissidens bryoides, Syntrichia fragilis, Mielichhoferia bryoides, Philonotis dregeana, Ptychomitrium crispatum, Fabronia pilifera, Pseudoleskeopsis claviramea, Leptodon smithii, and Hypnum cupressiforme are the most widespread.

Disjunct Cape Peninsula Subelement (3/5)

This subelement, the smallest of all the subelements, is centred in the Cape Peninsula (3318 C and 3418 A) with disjunct occurrences in the KwaZulu-Natal Midlands at Pietermaritzburg (2930 C), the Graskop-Blyderivierspoort area on the Mpumalanga escarpment (2430 D), and the Magaliesberg between Pretoria and Rustenburg (2527 C \& D, 2528 C). It is conspicuously absent from the high altitude areas of the Free State and Lesotho as well as large parts of the southern and Eastern Cape and KwaZulu-Natal (Fig. 11).

The Cape endemic Trematodon pillansii (Dicranaceae) is the only species more or less restricted to the main centre of distribution while Weissia latiuscula (Pottiaceae) and Bryum capillare (Bryaceae) are only found in the northern regions. The wide geographical distribution 
of this subelement is attained through species such as Sphagnum truncatum, Pseudocrossidium porphyreoneurum, Syntrichia pagorum, Bryum capillare, and Fabronia pilifera.

\section{Drakensberg Subelement (3/6)}

This element consists mostly of acrocarpous species distributed in drier areas of the Afromontane region and beyond. The main distribution area is situated in the Midlands and Drakensberg region of Kwazulu-Natal, and the eastern Free State down to the Zastron-Lady Grey area (Fig. 12). Significant numbers of species are also present along the escarpment in northern Swaziland and Mpumalanga, the Magaliesberg west of Pretoria, and the mountains of the Cape Peninsula and Boland. The main centre of distribution is situated in the KwaZulu-Natal Drakensberg (2828 D, 2929 A \& C) with secondary centres in the Graskop-Blyderivierspoort area of Mpumalanga (2430 D) and Table Mountain in the Western Cape (3318 C).

Species more or less restricted to the main Drakensberg centre of distribution are:

Distichium capillaceum, Aongstroemia julacea, Barbula microcalycina, Bryum caespiticium and Pohlia cruda. Widespread species include: Fissidens bryoides, Hypodontium dregei, Syntrichia fragilis, Campylopus introflexus, Brachymenium acuminatum, Philonotis dregeana, Philonotis falcata, Ptychomitrium crispatum and Hypnum cupressiforme.

Afromontane Forest Element (2/4)

By far the largest of the bryofloristic elements, with the highest percentage of FSA endemics (Appendix S2), the Afromontane Forest Element contains most of the (sub-)tropical forest 
species belonging to the pleurocarpous Orders of Isobryales, Hookeriales, Thuidiales, and Hypnobryales. However, a number of xerophytic taxa such as species of Archidium (Archidiaceae) and Ephemerum (Ephemeraceae) share a similar distribution pattern.

The Afromontane Forest Element is mainly distributed in the KwaZulu-Natal Midlands and Drakensberg area, and along the escarpment of Mpumalanga and Limpopo (Fig. 6). The two main centres of distribution are Blyderivierspoort (2430 D) and Pietermaritzburg (2930 C).

Other areas of relatively high species diversity are: (1) Table Mountain in the Western Cape (3318 C), (2) the Knysna and Tsitsikamma forests at George (3322 C) and Knysna (3423 A), (3) forests in the Amathole Mountains near King William's Town (3227 C), (4) the Zululand forests in the Empangeni- Eshowe area (2831 C \& D), and (5) the Soutpansberg forests in Limpopo (2230 C). Compared to the Afromontane Grassland Element, fewer species are distributed in the mountains of the south-western Cape, the eastern Free State, Magaliesberg, and the semi-arid central and western parts of the study area.

The following species are restricted to the Graskop-Blyderivierspoort centre of distribution: Campylopus fragilis, Campylopus jamesonii, Platyhypnidium macowanianum, Rhacopilopsis transvaaliensis, Rigodium toxarion, Syrrhopodon asper and Trachypodopsis serrulata. Species more or less restricted to the KwaZulu-Natal centre of distribution include: Drepanocladus aduncus, Fissidens enervis, Oligotrichum afrolaevigatum, Plagiobryum zierii, Pterobryopsis rehmannii and Stoneobryum mirum. The following species are widespread and occur in forest areas from Table Mountain in the Cape to the Soutpansberg in Limpopo: Aerobryopsis capensis, Brachymenium pulchrum, Fissidens glaucescens, Hypopterygium laricinum, Macrocoma tenue subsp. tenue, Neckera valentiniana, Polytrichum commune, Porotrichum madagassum, Pyrrhobryum spiniforme and Sematophyllum dregei. 
Widespread Afromontane Subelement (3/7)

Species in this group are widespread throughout the southern African part of the Afromontane Region or the Drakensberg regional mountain system (Domain) of White (1978) and Denys (1980). The family Catagoniaceae, represented by the endemic Catagonium nitens ssp.

maritimum, is restricted to this subelement. The main distribution areas are: (1) the escarpment forests of the northern provinces, from the Soutpansberg in the north to Swaziland in the south, (2) the Magaliesberg kloof forests between Pretoria and Rustenburg, (3) forests of the KwaZuluNatal Midlands and Drakensberg, (4) forests of the Eastern Cape Province, (5) the Knysna and Tsitsikamma forests, and (6) forests on Table Mountain and the Somerset West-Betty's Bay area of the Western Cape (Fig. 13). The main centres of distribution are: (1) the GraskopBlyderivierspoort area (2430D) on the Mpumalanga escarpment, and (2) the forests around Pietermaritzburg (2930 C) in the KwaZulu-Natal Midlands.

Only a few species are more or less restricted to the northern centres of distribution (Archidium acanthophyllum, Campylopus perpusillus, Leptodictyum riparium) or reach their southern limit in the Eastern Cape (Anomobryum filiforme, Hedwigia ciliata, Lindbergia viridis, Thuidium matarumense). Most species of this subelement occur in the south as well as the north of the distribution area and the following are among the most widespread: Spagnum capense, Fissidens glaucescens, Campylopus pyriformis, Campylopus robillardei, Macrocoma tenue subsp. tenue, Brachythecium implicatum, Sematophyllum brachycarpum, Sematophyllum dregei and Polytrichum commune. Species which range into the arid western parts of the study area 
include: Erpodium coronatum subsp. transvaaliense, Philonotis hastata and Physcomitrium spathulatum var. spathulatum.

Tropical Afromontane Subelement (3/8)

This is the largest of the bryofloristic subelements. Pleurocarpous species of the Orthotrichales, Isobryales, Hookeriales, Thuidiales and Hypnobryales are particularly well represented in the Tropical Afromotane Subelement, and $83 \%$ of species (including the FSA endemics) display (sub-)tropical distribution patterns. Taxa restricted to the top of the Lesotho escarpment, (e.g. Quathlamba debilicostata and Orthotrichum armatum) may actually belong to the Mont Aux Sources Subelement (Eastern Highlands Element) but are classified here as a result of the course grain of the data set.

Although widespread in the eastern and southern parts of the study area, this subelement is concentrated in two main centres of distribution: (1) the Mpumalanga Drakensberg escarpment, in particular the Graskop-Blyderivierspoort area (2430 D), and (2) the KwaZuluNatal Midlands and Drakensberg, especially the Pietermaritzburg area (grid 2930 C) (Fig. 14).

Other areas of relatively high species concentrations are: (1) the montane forests in the Tzaneen-Haenertzburg area of Limpopo, (2) the Zululand forests around Empangeni and Eshowe, (3) the forests of the Amathole Mountains north of King William's Town in the Eastern Cape Province, (4) the Outeniqua Mountains near George in the Western Cape, and (5) the Afromotane forest on the slopes of Table Mountain.

The following species are more or less restricted to the two main areas of distribution: Brachymenium leptophyllum, Brachymenium nepalense, Calymperes pallidum, Campylopus 
fragilis, Campylopus jamesonii, Floribundaria floribunda, Leptodontium longicaule, Leucoloma chrysobasilare, Levierella perserrata, Pogonatum oligodus, Porotrichum elongatum and Rhabdoweisia fugax. Mosses restricted to the Mpumalanga centre of distribution include: Platyhypnidium macowanianum, Rhacopilopsis transvaaliensis, Rigodium toxarion, Syrrhopodon asper and Trachypodopsis serrulata. The following are examples of mosses more or less restricted to the KwaZulu-Natal centre of distribution: Drepanocladus aduncus, Fissidens enervis, Oligotrichum afrolaevigatum, Plagiobryum zierii, Stoneobryum mirum. Widespread species include Aerobryopsis capensis, Atrichum androgynum, Brachymenium pulchrum, Ditrichum brachypodum, Hypopterygium laricinum, Neckera valentiniana, Porothamnium stipitatum, Porotrichum madagassum, Pyrhobryum spiniforme, Racopilum capense and Sematophyllum subpinnatum. Species responsible for this subelement's distribution in the semiarid central and northern parts are: Brachymenium systylium, Erpodium beccarii, Erpodium grossirete, Fissidens capriviensis, Fissidens erosulus, Fissidens submarginatus, Fissidens subobtusatus, Hyophila baginsensis and Vesicularia galerulata.

\section{DISCUSSION}

The two main elements

The TWINSPAN classification has successfully distinguished between a group of xerophytic mosses, mainly distributed in the semi-arid to arid, temperate south-western and central parts of southern Africa, and a mesophytic group distributed in more stable, subtropical habitats in the eastern and southern parts of the study area. The species classification therefore follows the same 
pattern as the grid classification where the study area was divided into a semi-arid, temperate, south-western region with a xerophytic moss flora, and a subtropical region in the northern and eastern parts, extending southward along the coast, with a mesophytic moss flora (van Rooy \& van Wyk, 2010).

The distribution area of the Xerophytic element coincides with that of the montane palaeogenic element of Stuckenberg (1962) and the Cape-Afromontane group (of genera) of Goldblatt (1978). It also coincides with the high altitude areas of an Afrotemperate Track mentioned by Kurzweil et al. (1991). Although Weimarck's (1941) elements refer to distribution patterns within the Cape flora only, the bryofloristic element displays a distribution pattern similar to that of his Cape element.

The Mesophytic element is probably part of an East African or Afromontane element (Weimarck 1941, Hodgetts et al. 1999), also called the African track (Linder et al. 1992), distributed throughout the Afromontane areas of Africa. The southern part of the Afromontane element, from Malawi down to the Cape, has been described as the South African element by Clayton (1975).

The distribution area of the Mesophytic element more or less coincides with the Northeastern distribution of tropical and subtropical (grass) species of Acocks (1971) and the distribution area of mixed evergreen forests in southern Africa (Geldenhuys, 1994). The Mpumalanga (bryofloristic) Centre of distribution coincides with the Barberton Centre of Croizat (1965), Nordenstam (1969) and Hilliard (1994).

The main distribution areas of the Xerophytic and Mesophytic elements overlap at several points along the eastern escarpment of southern Africa. The Xerophytic element is more or less evenly distributed in the two main bryofloristic regions of van Rooy \& van Wyk (2010), 
the temperate and subtropical regions, while the widespread, Mesophytic element is mainly distributed in the subtropical region (Fig. 15).

\section{Eastern Highlands Element}

This element is named after the Eastern Highlands Centre of Stuckenberg (1962). The main distribution area overlaps with that of The Drakensberg Group (Eastern Mountain Region), also described as The Drakensberg (endemic) Centre, as well as The Sneeuwberg-Drakensberg Group (species) of Nordenstam (1969), Hilliard \& Burtt (1987), Kurzweil et al. (1991) and Hilliard (1994).

The Eastern Highlands Element is mainly distributed in the Highlands and Afromontane Regions but the Afromontane distribution is probably exaggerated as a result of grid squares spanning the Lesotho/KwaZulu-Natal escarpment (Fig. 15).

Given the distribution of this element it is not surprising to find that most species $(92 \%)$ occur in the Grassland Biome, a large percentage (72\%) are found in the Nama-Karoo Biome, especially the north-eastern Lesotho 'island' which coincides with the centre of distribution, and relatively few species (30\%) are found in forest areas (Appendix S3).

\section{Mont Aux Sources Subelement}

The distribution area of the Mont Aux Sources Subelement is congruent with the BasutolandDrakensberg Highlands and Eastern Plateau Slopes subcentre of Stuckenberg (1962). It is mainly distributed in the Drakensberg Alpine Domain of van Rooy \& van Wyk (2010) with a secondary 
peak in the Cape Domain (Fig. 15). As in the Eastern Highlands Element, most of the species in this subelement occur in the Grassland (89\%) and Nama-Karoo (71\%) Biomes (Appendix S3).

\section{Widespread Subelement}

The concentration of species along the Mpumalanga escarpment has been described as the Eastern Transvaal Subcentre by Stuckenberg (1962). The Widespread Subelement has its main centre of distribution in the Drakensberg Alpine Domain but is well represented in most domains (Fig. 15). The lowest numbers of species occur in the Caprivi and Namaqua Domains. Several of the distribution centres within the Widespread Subelement can be attributed to collecting activity as well as the botanist effect (van Rooy, 2000; Moerman \& Estabrook, 2006).

Widespread in the summer rainfall area, all of the species are found in the Grassland and adjacent Savanna Biomes while few occur in the Succulent Karoo (33\%), and Desert Biomes (8\%, Appendix S3).

\section{Cape Element}

This element is named after the Cape Centre of Stuckenberg (1962). It is distributed in more or less the same area as Weimarck's (1941) Species endemic in the Cape Proper, the Cape Species of Nordenstam (1969), the western type of distribution of Acocks (1971), the combined Karoo-margin species and Cape Floristic Centre of Kurzweil et al. (1991), and phytogeographical Group A (Cape species) of Hilliard (1994). Unlike the seed plant elements, up to $18 \%$ of the mosses in the Cape Element occur to the east of the Cape area. The main 
distribution area of the Cape Element compares favourably with that of Weimarck's (1941) Cape Ubiquists with a Knysna Interval. Weimarck (1941) classified Cape elements with wide distributions as The Cape Ubiquists.

The three endemic genera of this TWINSPAN element, as well as the recently described Ludorugbya, Algaria and Acaulonopsis (Hedderson \& Zander, 2007, 2008b; Zander \& Hedderson, 2009) are monotypic and restricted to the main distribution area of the Cape Element. This may indicate a possible origin in the Pliocene as a result of the inception of a Mediterranean type climate in the Cape (Deacon, Jury \& Ellis, 1992). However, Frey (1990) is of the opinion that a Mediterranean-type distribution pattern, which he described as the Xerothermic Pangaean genoelement, is an ancient one, supposedly of pre-angiosperm origin.

The Cape Element is centred in the southern part of the Afromontane Region or the Cape Domain but this may be exaggerated as a result of the coarse grain and the phytogeographical heterogeneity of the area. As expected, the Cape Element is well represented in the Karoo-Namib Region (Fig. 15).

The main distribution area of the Cape Element coincides with the western part of the Fynbos Biome (83\% of species) while more than half of the species (55\%) ranges northwards into the Succulent Karoo Biome (Appendix S3). The main distribution area does not include many forest areas and this is reflected in the low percentage of Cape species found in the Forest Biome (19\%). 


\section{West Coast Subelement}

Both subdevisions of the Cape Element have their main centres of distribution in the Cape Peninsula and therefore overlap in the south-western Cape area. The distribution area of the West Coast Subelement more or less coincides with that of the Western phytogeographic groups of Weimarck (1941), Dahlgren (1963) and Nordenstam (1969), and the Nearly (Cape) ubiquitous species concentrated in the west of Dahlgren (1963).

One of the main centres of distribution, the Cape Town or Table Mountain centre (Fig. 9), coincides with the Cape Peninsula Subcentre (South Western Centre) of Weimarck (1941) while the Clanwilliam centre more or less coincides with his Cedarberg Subcentre (North Western Centre). The distribution centre in Namaqualand overlaps with the Kamiesberg Subcentre (North -Western Centre) of Weimarck (1941). The concentration of species in the Richtersveld has been described as the Gariep Centre by Croizat (1965), Nordenstam (1969) and Hilliard (1994). It should be noted, however, that the name Gariep Centre has more recently been applied to a chorological subdivision of the Western Cape Domain or the Succulent Karoo (Hilton-Taylor, 1987, 1994, 1996; Cowling et al. 1999), as well as a centre of plant endemism (van Wyk \& Smith, 2001).

The West Coast Subelement is mainly distributed in the winter rainfall Cape and Western Cape Domains with a minor peak in the Drakensberg Alpine Domain (Fig. 15). Both subdivisions of the Cape element are completely absent from the Caprivi Domain.

The two main centres of distribution fall in the Fynbos Biome (75\% of species) but the main distribution area extends into the adjacent Succulent Karoo Biome (72\% of species, Appendix S3). 


\section{Boland Subelement}

The main distribution area of the Boland Subelement coincides with that of Weimark's (1941) Western Group or the South-Western Centre, and Hilliard's (1994) South western Group. The centre of distribution (Table Mountain) coincides with Weimarck's (1941) Cape Peninsula Subcentre. The concentrations of species in grids $3318 \mathrm{D}$ and $\mathrm{C}$ have been described as the Hottentotsholland and French Hoek Subcentres by Weimarck (1941).

Not surprisingly the Boland Subelement is largely confined to the Cape Domain (Fig. 15) and the only subelement with all of its species occuring in the Fynbos Biome (Appendix S3).

\section{Afromontane Grassland Element}

The Afromontane Grassland Element is mainly distributed in the Afromontane Region of van Rooy \& van Wyk (2010) with minor peaks in the Zambezian and Highlands Regions (Fig. 15).

As the name implies, almost all of the species occur in the Grassland Biome (94\%), and large numbers in its southern Afromontane replacement, the Fynbos Biome (64\%), as well as the Savanna Biome (76\%). This element is further characterised by the relatively large numbers of species present in the semi-arid Succulent Karoo (22\%) and Nama-Karoo (56\%) Biomes compared to only $0.16 \%$ and $11 \%$ of the Afromontane Forest Element. The southern centre of distribution is evident in the relatively high percentage of species (64\%) present in the Fynbos Biome compared to the $45 \%$ of the Afromontane Forest Element (Appendix S3). 


\section{Disjunct Cape Peninsula Subelement}

The Disjunct Cape Peninsula Subelement is most abundant in the Cape Domain with secondary occurrences in the Drakensberg, Bushveld and Caprivi Domains (Fig. 15).

Eighty two percent of species occur in each of the Grassland, Savanna and Fynbos Biomes where the disjunct centres of distribution are located (Appendix S3). Although Afromontane forests are present in all the centres, only $27 \%$ of species were recorded from this biome.

\section{Drakensberg Subelement}

This subelement is most abundant in the Cape and Drakensberg Domains and a significant number of species are present in the Drakensberg Alpine Domain (Fig. 15). Almost all of the species (96\%) occur in the Grassland Biome and large numbers are also present in the Savanna (75\%), Forest (62\%), Nama-Karoo (62\%), and Fynbos (60\%) Biomes (Appendix S3). The

relatively large number of species distributed in the Nama-Karoo Biome (62\%) is only as a result of this biome's presence in the north-eastern part of Lesotho, the main centre of distribution.

\section{Afromontane Forest Element}

The distribution areas of the Afromontane Forest and Afromontane Grassland Elements overlap, except in Namaqualand and southern Namibia where the Afromontane Forest Element is absent. Like the Afromontane Grassland Element, the Afromontane Forest Element is largely restricted 
to the Afromontane Region (Fig. 15), but the proportion of forest elements (55\%) is higher as fewer species occur in the Grassland (76\%) and Savanna (59\%) Biomes (Appendix S3).

\section{Widespread Afromontane Subelement}

Surprisingly this subelement is most abundant in the Cape Domain and not the Drakensberg Domain where the main centres of distribution are situated (Fig. 15). Both Afromontane Forest subdivisions are absent from the arid Namaqua Domain.

The species are abundant in each of the biomes found along the Afromontane region, i.e. the Grassland (94\%), Savanna (92\%), Forest (76\%) and Fynbos (80\%) Biomes (Appendix S3). The widespread nature of this subelement is also evident in the relatively high percentage (63\%) of species that occur in all of these biomes (Grassland, Forest, Savanna as well as the Fynbos Biome) compared to only $16 \%$ of species in the Tropical Afromontane Subelement.

\section{Tropical Afromontane Subelement}

As the name indicates, this subelement is most abundant in subdivisions of the Afromontane Region, the Drakensberg and Cape Domains (Fig. 15). Most species are found in the Grassland Biome $(73 \%)$ while only about half of the species occur in each of the Forest (51\%) and Savanna (52\%) Biomes (Appendix S3). The northern bias of this subelement is illustrated by the

relatively low percentage of species (39\%) present in the Fynbos Biome compared to $80 \%$ of the Widespread Afromontane Subelement. 


\section{Bryogeographical hotspot}

Three of the four bryofloristic elements are centred in the Afromontane (bryofloristic) Region while five of the eight subelements are centred in the Cape Domain (Fig. 15). This stresses the phytogeographical importance of the Afromontane islands in the southern and south-western Cape, especially the Table Mountain locality, which is a centre of distribution for most bryofloristic elements and subelements. This centre falls in a high priority area for conserving habitat (Rouget et al. 2006) and can therefore be regarded as a bryogeographical hotspot.

\section{SUPPLEMENTARY INFORMATION}

Additional Supplementary Information may be found in the online version of the article:

Figure S1. The study area

Figure S2. Dendrogram of the TWINSPAN 3+ species classification

Appendix S1. The bryofloristic elements of southern Africa

Appendix S2. Diversity and endemism of the bryofloristic elements

Appendix S3. Abundance of bryofloristic elements in biomes

\section{ACKNOWLEDGEMENTS}

The facilities and funding provided by the Acting Curator of the National Herbarium in Pretoria, Ms E. Rampho, are gratefully acknowledged. Professional assistance by Me Hester Steyn is much appreciated. 


\section{REFERENCES}

Acocks JPH. 1971. The distribution of certain ecologically important grasses in South Africa. Mitteilungen der Botanischen Staatssammlung München 10: 149-160.

Carbutt C, Edwards TJ. 2006. The endemic and near-endemic angiosperms of the Drakensberg Alpine Centre. South African Journal of Botany 72: 105-132.

Clayton WD. 1975. The chorology of African grasses. Kew Bulletin 31: 273-288.

Cowling RM. 1983. Phytochorology and vegetation history in the south-eastern Cape, South Africa. Journal of Biogeography 10: 393-419.

Cowling RM, Pressey RL, Lombard AT, Desmet PG, Ellis AG. 1999. From representation to persistence: requirements for a sustainable system of conservation areas in the speciesrich Mediterranean-climate desert of southern Africa. Diversity and Distributions 5: 5171.

Croizat L. 1965. An introduction to the subgeneric classification of Euphorbia L., with stress on the South African and Malagasy species. I. Webbia 20: 573-706.

Dahlgren R. 1963. Studies on Aspalathus: phytogeographical aspects. Botaniska Notiser 116: $431-472$.

Deacon HJ, Jury MR, Ellis F. 1992. Selective regime and time. In: Cowling RM, ed. The ecology of fynbos. Nutrients, fire and diversity. Cape Town: Oxford University Press, 622.

Denys E. 1980. A tentative phytogeographical division of tropical Africa based on a mathematical analysis of distribution maps. Bulletin Jardin Botanique National de Belgique 50: 465-504. 
Frey W. 1990. Genoelemente prä-angiospermen Ursprungs bei Bryophyten. Botanische Jahrbücher für Systematik, Pflanzengeschichte und Pflanzengeographie 111: 433-456.

Geldenhuys CJ. 1994. Phytogeography of the southern Cape forest flora. In: Seyani JH, Chikuni AC, eds. Proceedings of the XIIIth Plenary Meeting of AETFAT, Zomba, Malawi, 2-11 April 1991. Zomba: National Herbarium and Botanic Gardens of Malawi, 969-992.

Goldblatt P. 1978. An analysis of the flora of southern Africa: its characteristics, relationships, and origins. Annals of the Missouri Botanical Garden 65: 369-436.

Hedderson TA, Zander RH. 2007. Ludorugbya springbokorum (Pottiaceae) a new moss genus and species from the Western Cape Province of South Africa. Journal of Bryology 29: $222-227$.

Hedderson TA, Zander RH. 2008a. Vrolijkheidia circumscissa (Pottiaceae), a new moss genus and species from the Succulent Karoo of South Africa. Journal of Bryology 30: 143-146.

Hedderson TA, Zander RH. 2008b. Algaria nataliei (Pottiaceae), a new moss genus and species from the Western Cape Province of South Africa. Journal of Bryology 30: 192195.

Hilliard OM. 1994. The Manuleae. A tribe of Scrophulariaceae. Edinburgh University Press. Hilliard OM, Burtt BL. 1987. The botany of the southern Natal Drakensberg. Cape Town, National Botanic Gardens.

Hilton-Taylor C. 1987. Phytogeography and origins of the Karoo flora. In: Cowling RM, Roux PW, eds. The Karoo Biome: a preliminary synthesis, Part 2-vegetation and history. Pretoria: FRD, 70-95. 
Hilton-Taylor C. 1994. Western Cape Domain (Succulent Karoo). In: Davis SD, Heywood VH, Hamilton AC, eds. Centres of plant diversity. A guide and strategy for their conservation, Vol. 1. Cambridge: IUCN Publications unit, 204-217.

Hilton-Taylor C. 1996. Patterns and characteristics of the Succulent Karoo Biome, southern Africa. In: van der Maesen LJG, van der Burgt XM, van Medenbach de Rooy JM, eds. The biodiversity of African plants. Dordrecht: Kluwer Academic Publishers, 58-72.

Hodgetts NG, Matcham HW, Duckett J.G. 1999. Bryophytes collected in Lesotho, the Natal Drakensberg and the Orange Free State, southern Africa. Journal of Bryology 21: 133155.

Horton DG. 1982. A revision of the Encalyptaceae (Musci), with particular reference to the north American taxa. Part I. Journal of the Hattori Botanical Laboratory 53: 365-418.

Kurzweil H, Linder HP, Chesselet P. 1991. The phylogeny and evolution of the PterygodiumCorycium complex (Coryciinae, Orchidaceae). Plant Systematics and Evolution 175: $161-223$.

Levyns MR. 1954. The genus Muraltia. Cape Town: Cape Times Ltd.

Linder HP, Meadows ME, Cowling RM. 1992. History of the Cape flora. In: Cowling RM, ed. The ecology of fynbos. Nutrients, fire and diversity. Cape Town: Oxford University Press, $113-134$.

Moerman DE, Estabrook GF. 2006. The botanist effect: counties with maximal species richness tend to be home to universities and botanists. Journal of Biogeography 33: 1969-1974.

Nordenstam B. 1969. Phytogeography of the genus Euryops (Compositae). Opera Botanica 23: $1-77$. 
O'Shea BJ. 1997. The mosses of sub-Saharan Africa 2. Endemism and biodiversity. Tropical Bryology 13: 75-85.

\section{Rouget M, Jonas Z, Cowling RM, Desmet PG, Driver A, Mohamed B, Mucina L,} Rutherford MC, Powrie LW. 2006. Ecosystem status and protection levels of vegetation types. In: Mucina L, Rutherford MC, eds. The vegetation of South Africa, Lesotho and Swaziland. Pretoria: South African National Biodiversity Institute, 725-737.

Russell S, van Rooy J. 1988a. The bryoflora of Namibia. In: Goldblatt P, Lowry II PP, eds. Modern systematic studies in African botany. St. Louis: Missouri Botanical Garden, 453460.

Russell S, van Rooy J. 1988b. Bryophyte diversity in the eastern Cape forests. In: Bruton MN, Gess FW, eds. Towards an environmental plan for the eastern Cape, being the proceedings of a conference held at Rhodes University to review the environmental problems of the eastern Cape. Grahamstown: Rhodes University, 136-143.

Rutherford MC, Westfall RH. 1986. Biomes of southern Africa - an objective categorization. Pretoria: Botanical Research Institute, Department of Agriculture and Water Supply.

Stuckenberg BR. 1962. The distribution of the montane palaeogenic element in the South African invertebrate fauna. Annales of the Cape Provincial Museum 2: 191-204.

van Rooy J. 2000. Diversity and phytogeography of the moss flora of southern Africa. Ph.D. thesis, University of Pretoria.

van Rooy J. 2003. Bryophyta. In: Germishuysen G, Meyer NL, eds. Plants of southern Africa: an annotated checklist. Pretoria: National Botanical Institute, 2-37.

van Rooy J, van Wyk AE. 2010. The bryofloristic regions of southern Africa. Journal of Bryology 32: $80-91$. 
van Wyk AE, Smith G. 2001. Regions of floristic endemism in southern Africa: a review with emphasis on succulents. Hatfield, South Africa: Umdaus Press.

Weimarck H. 1941. Phytogeographical groups, centres and intervals within the Cape flora. Lunds Universitets Årsskrift 37: 1-143.

White F. 1978. The Afromontane Region. In: Werger MJA, ed. Biogeography and ecology of southern Africa. The Hague: W. Junk, 463-513.

Zander RH. 1993. Genera of the Pottiaceae: mosses of harsh environments. Bulletin of the Buffalo Society of Natural Sciences, volume 32. Buffalo, New York: The Buffalo Society of Natural Sciences.

Zander RH, Hedderson TA. 2009. Acaulonopsis, a new moss genus of the Pottiaceae from Western Cape Province of South Africa, and comments on Vrolijkheidia. Journal of Bryology 31: 234-239.

JACQUES VAN ROOY, National Herbarium, South African National Biodiversity Institute, Private Bag X101, Pretoria 0001, South Africa. E-mail: j.vanrooy@ sanbi.org.za (corresponding author)

ABRAHAM E. VAN WYK, H.G.W.J. Schweikerdt Herbarium, Department of Plant Science, University of Pretoria, Pretoria 0002, South Africa. E-mail: braam.vanwyk@up.ac.za

FIGURES AND TABLE 


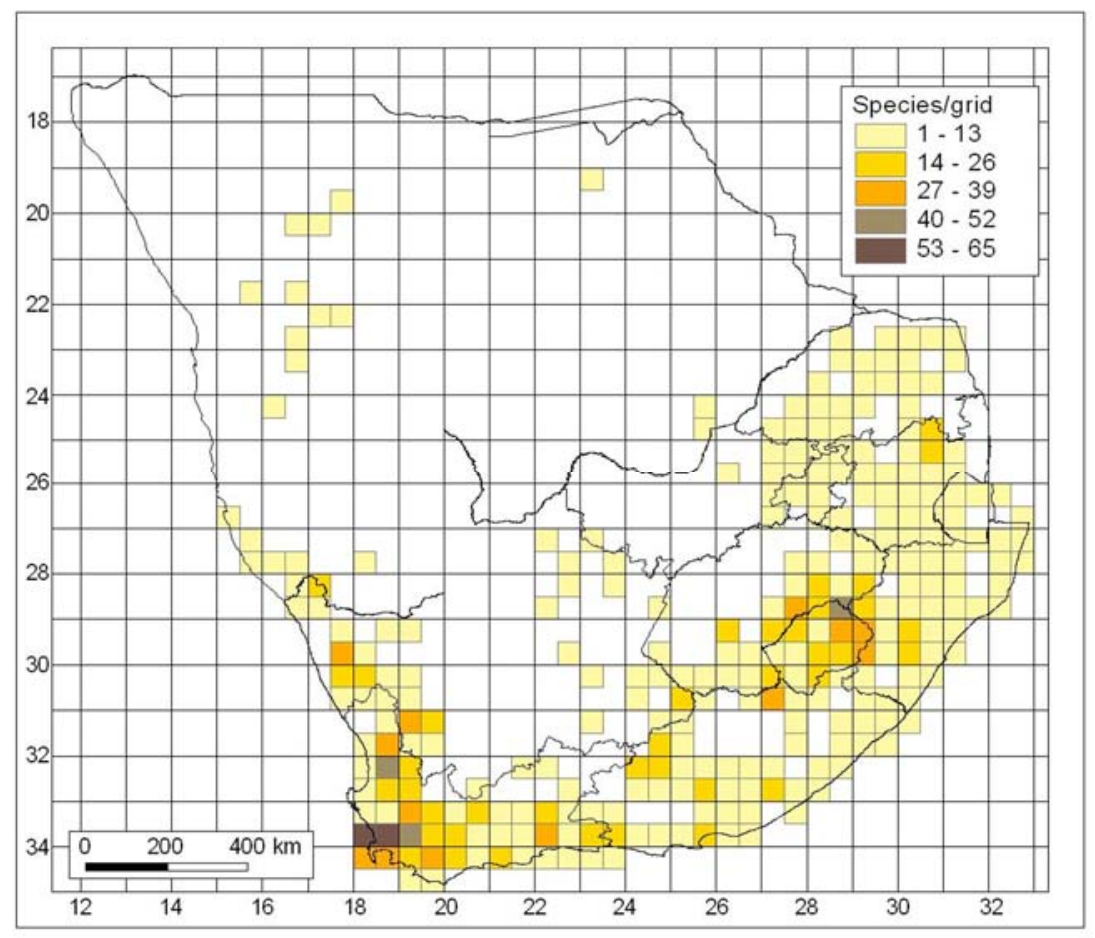

Figure 1. Geographical distribution of the Xerophytic element

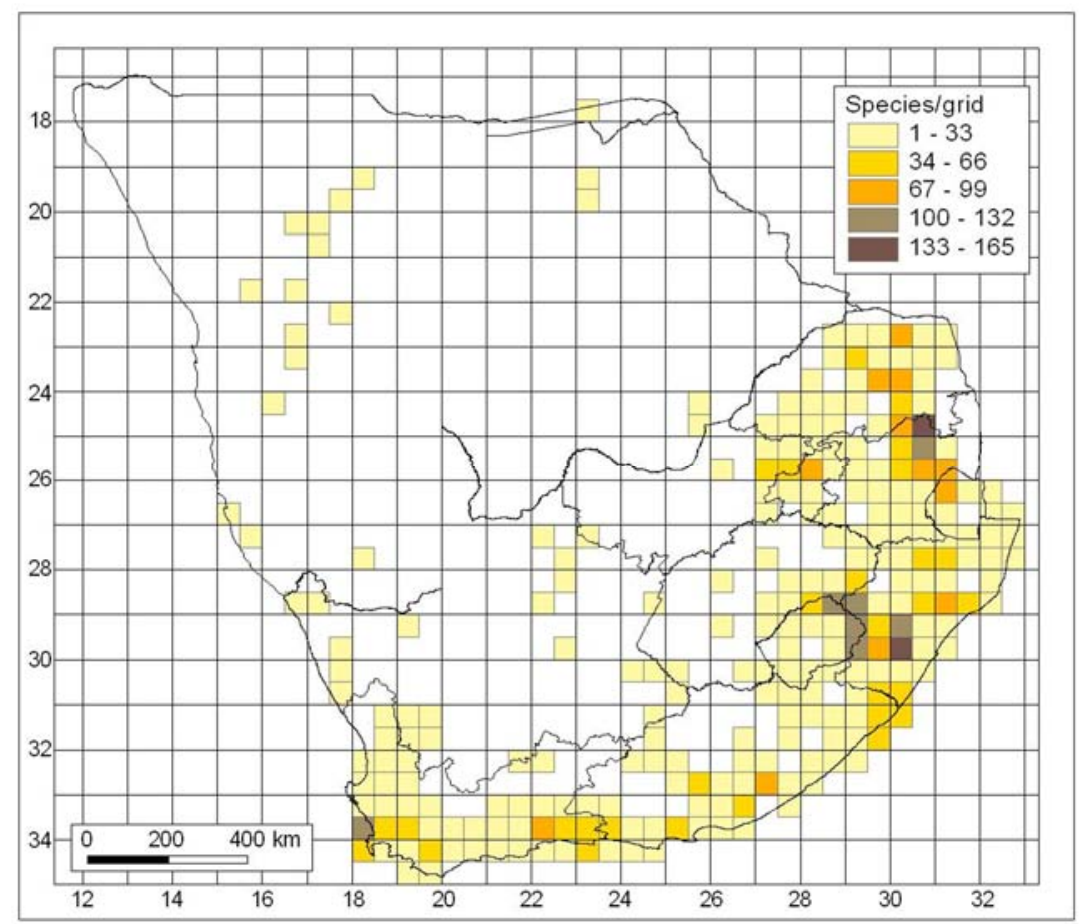

Figure 2. Geographical distribution of the Mesophytic element 


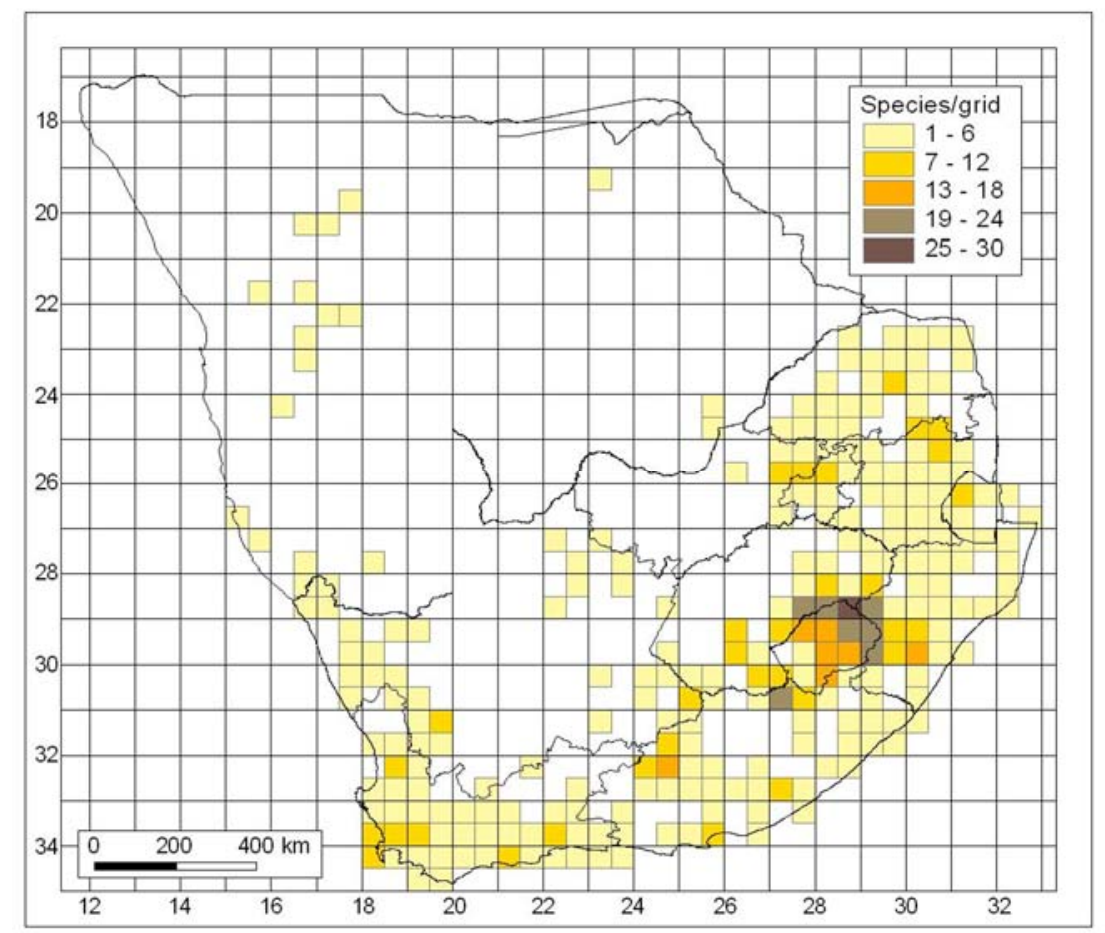

Figure 3. Geographical distribution of the Eastern Highlands Element

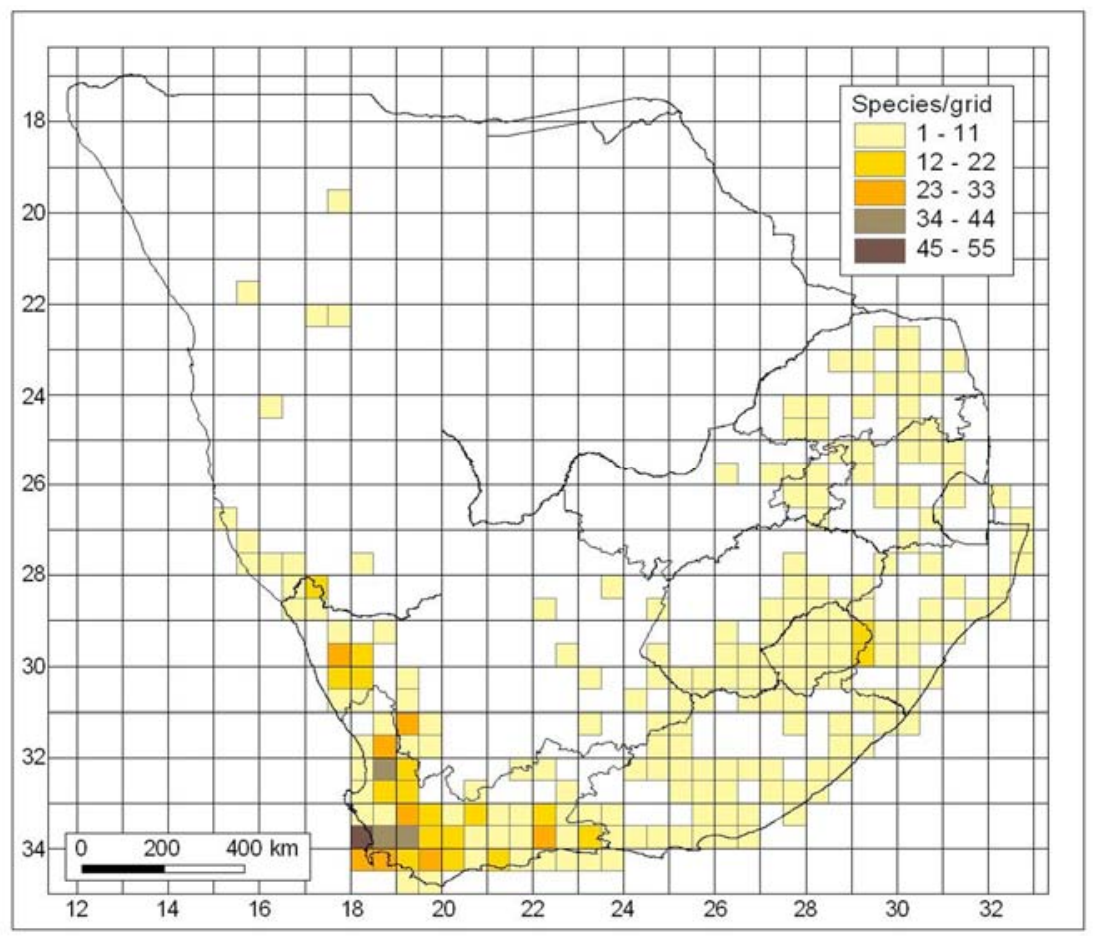

Figure 4. Geographical distribution of the Cape Element 


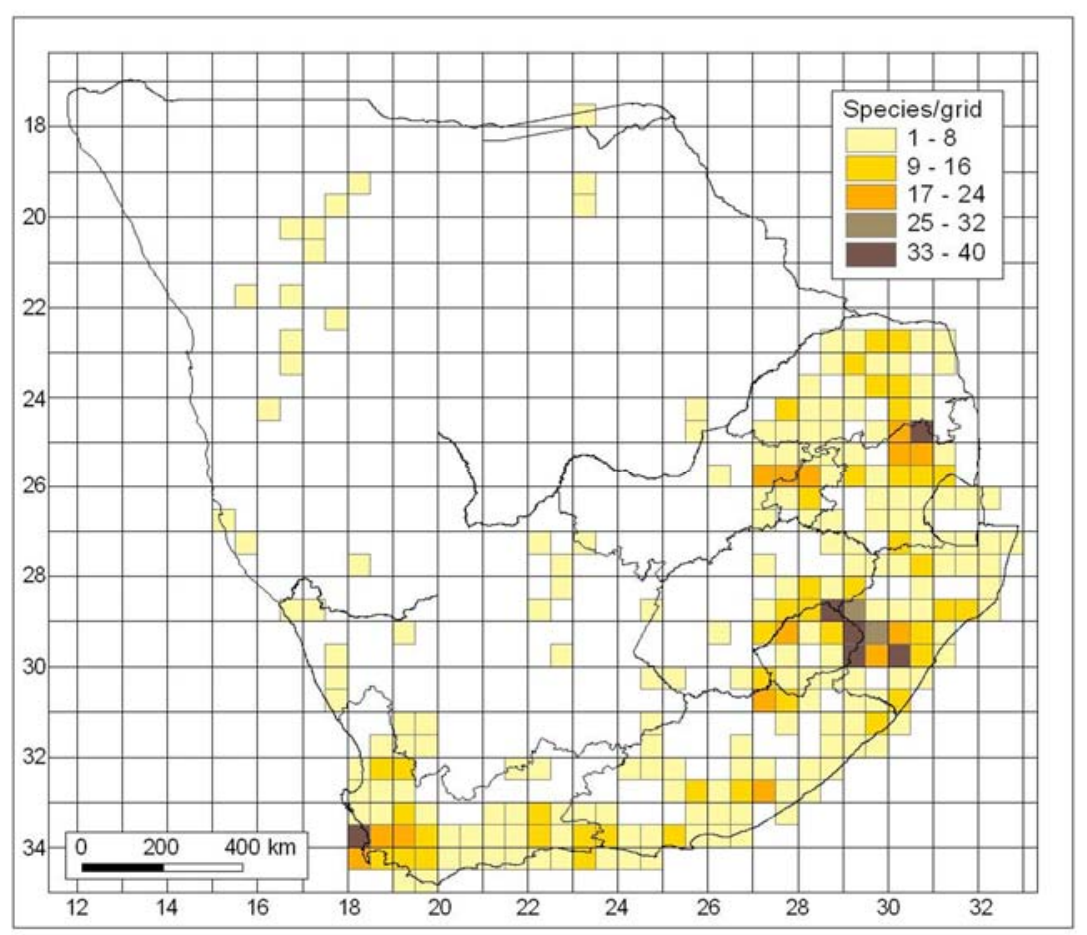

Figure 5. Geographical distribution of the Afromontane Grassland Element

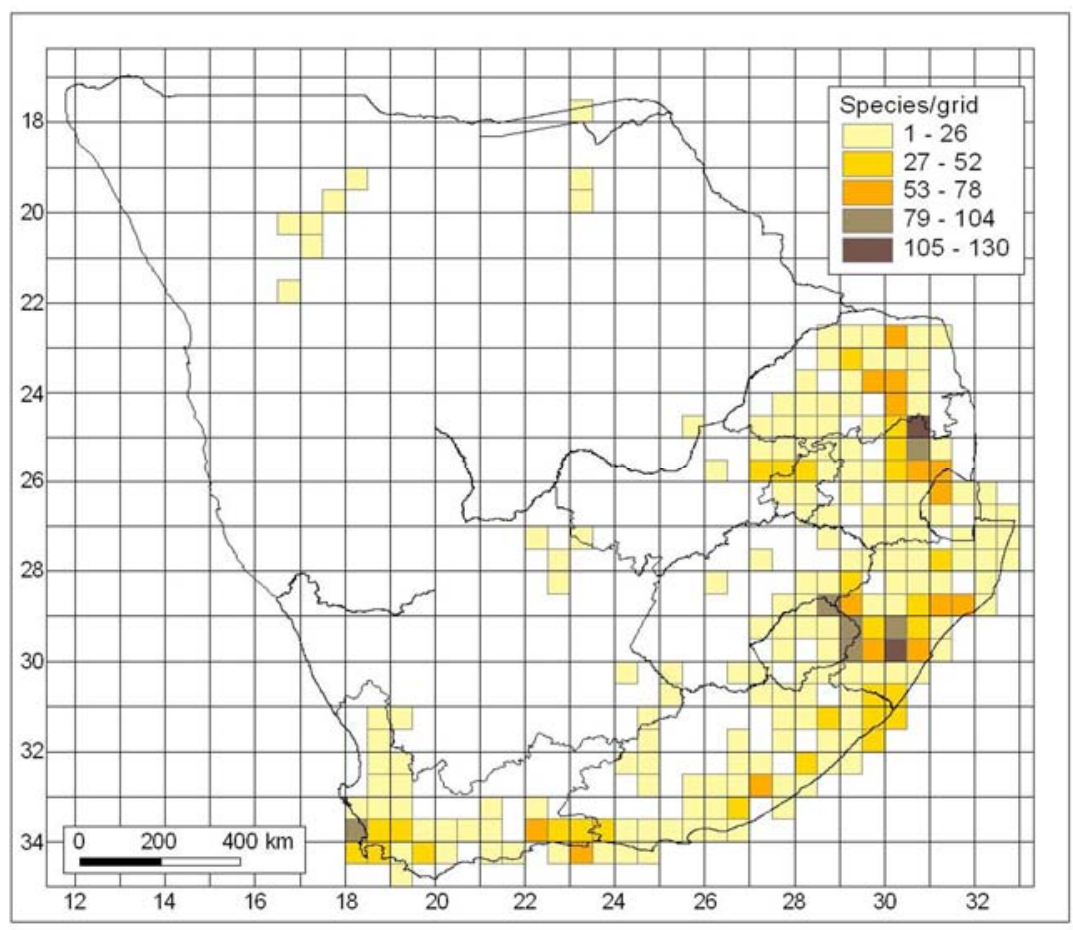

Figure 6. Geographical distribution of the Afromontane Forest Element 


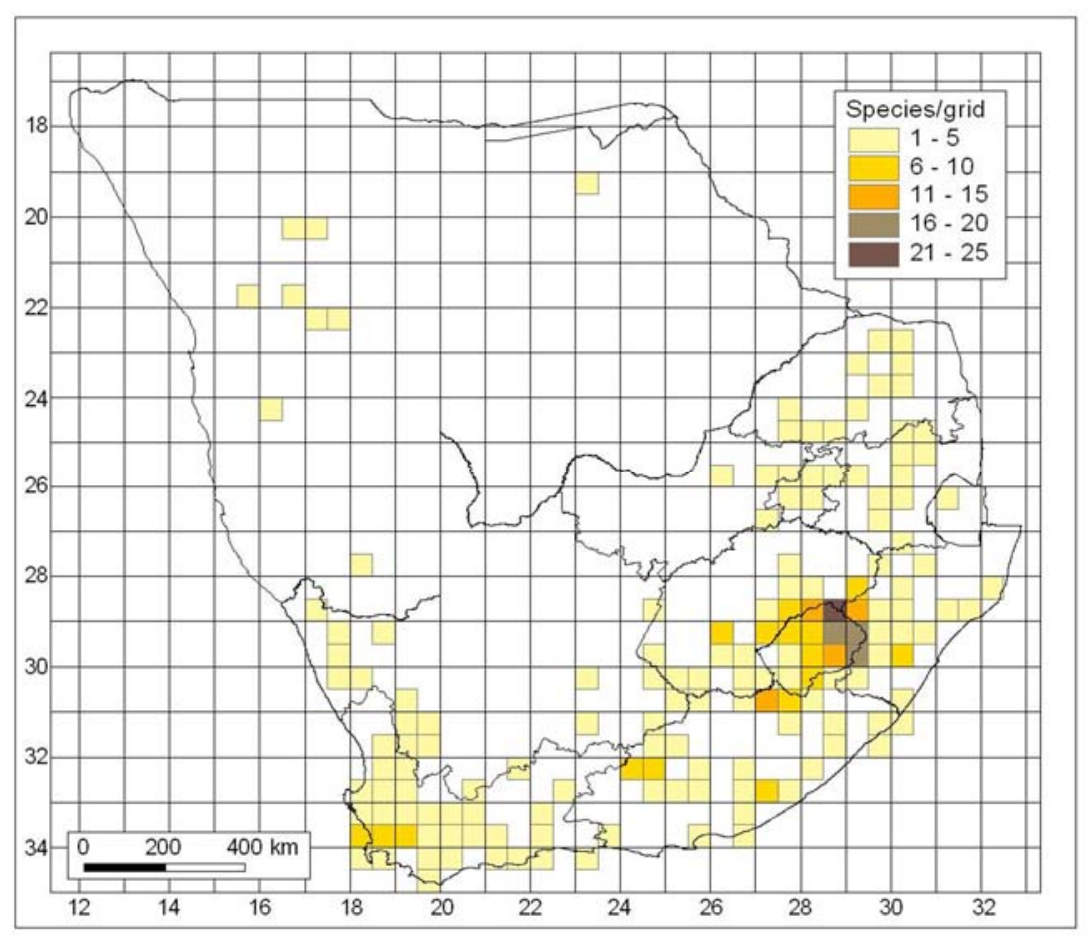

Figure 7. Geographical distribution of the Mont aux Sources Subelement

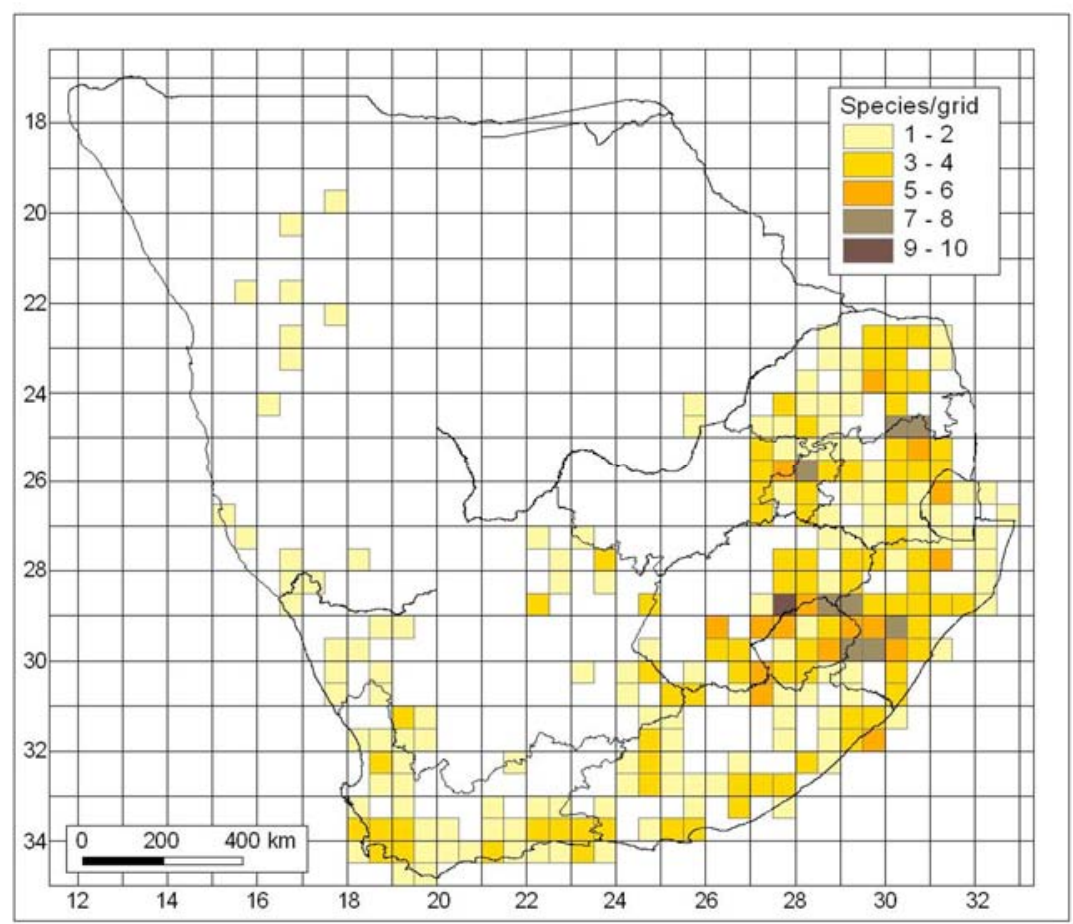

Figure 8. Geographical distribution of the Widespread Subelement 


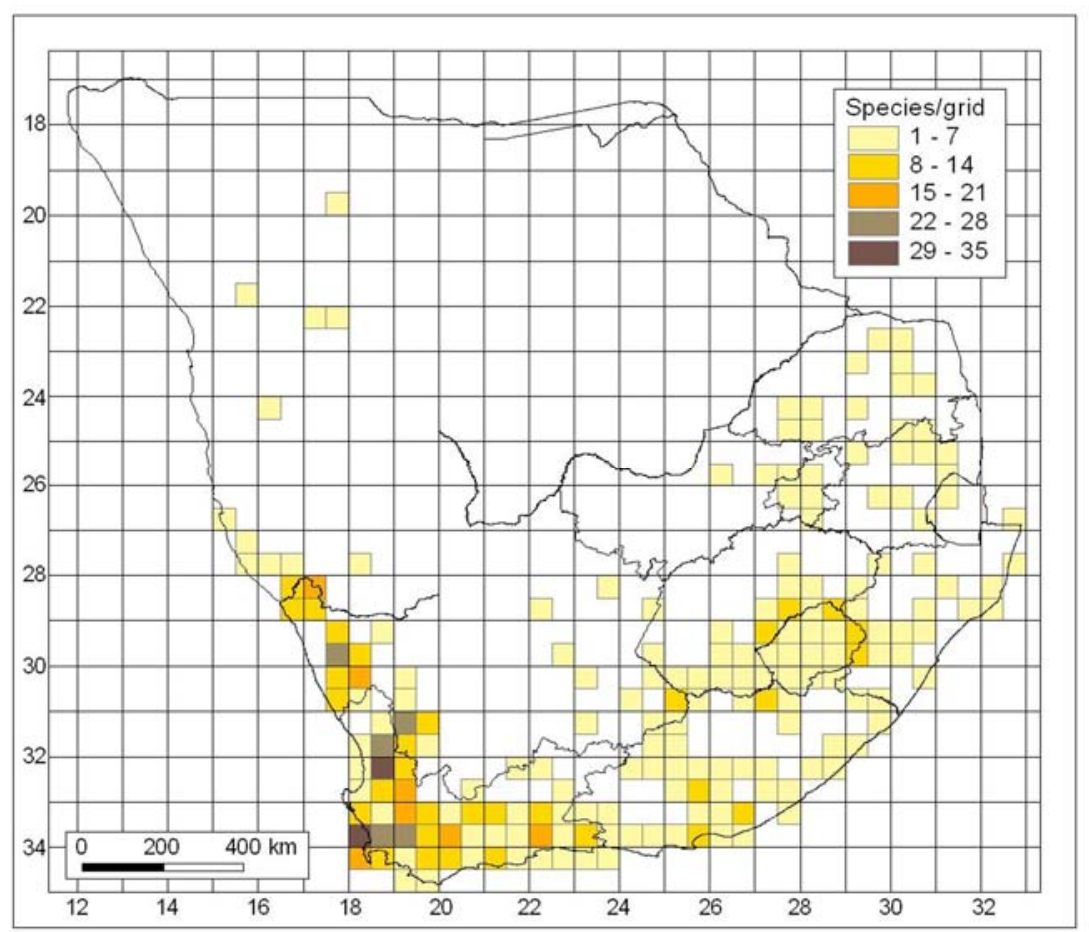

Figure 9. Geographical distribution of the West Coast Subelement

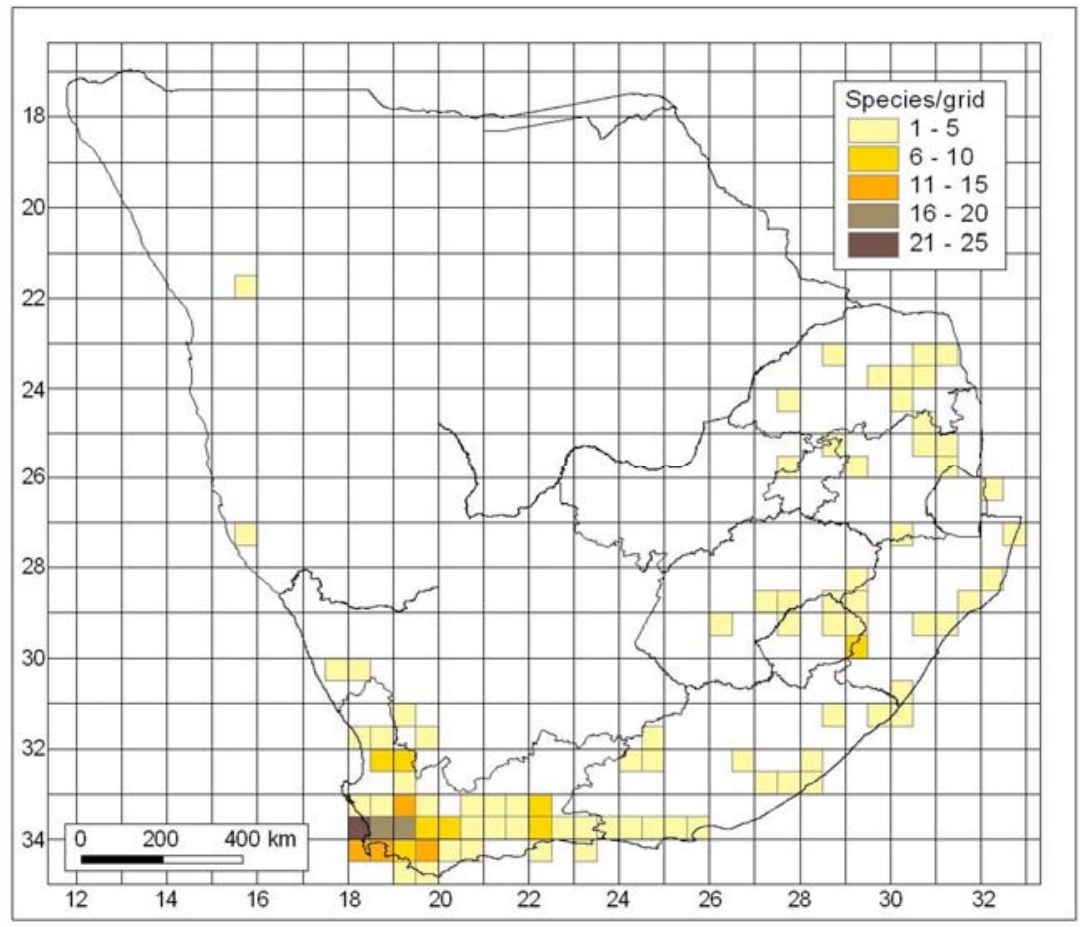

Figure 10. Geographical distribution of the Boland Subelement 


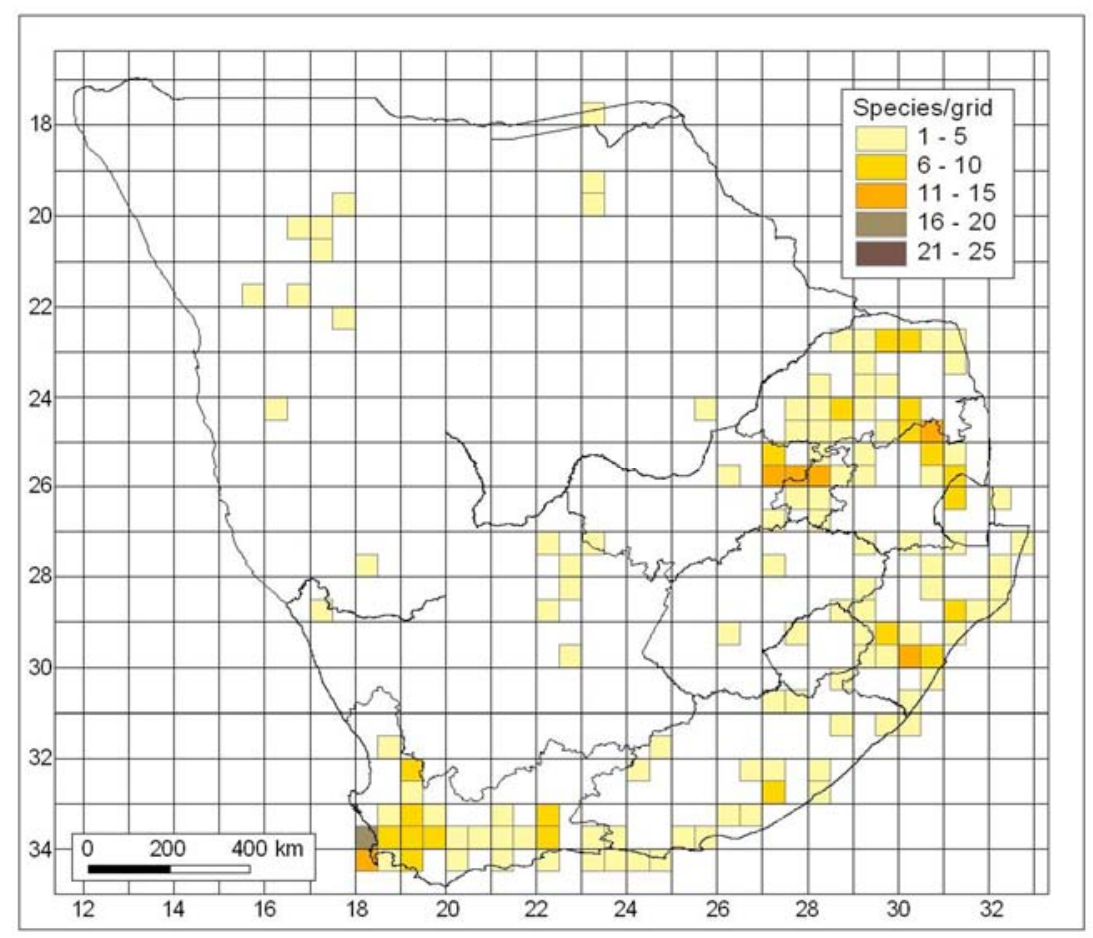

Figure 11. Geographical distribution of the Disjunct Cape Peninsula Subelement

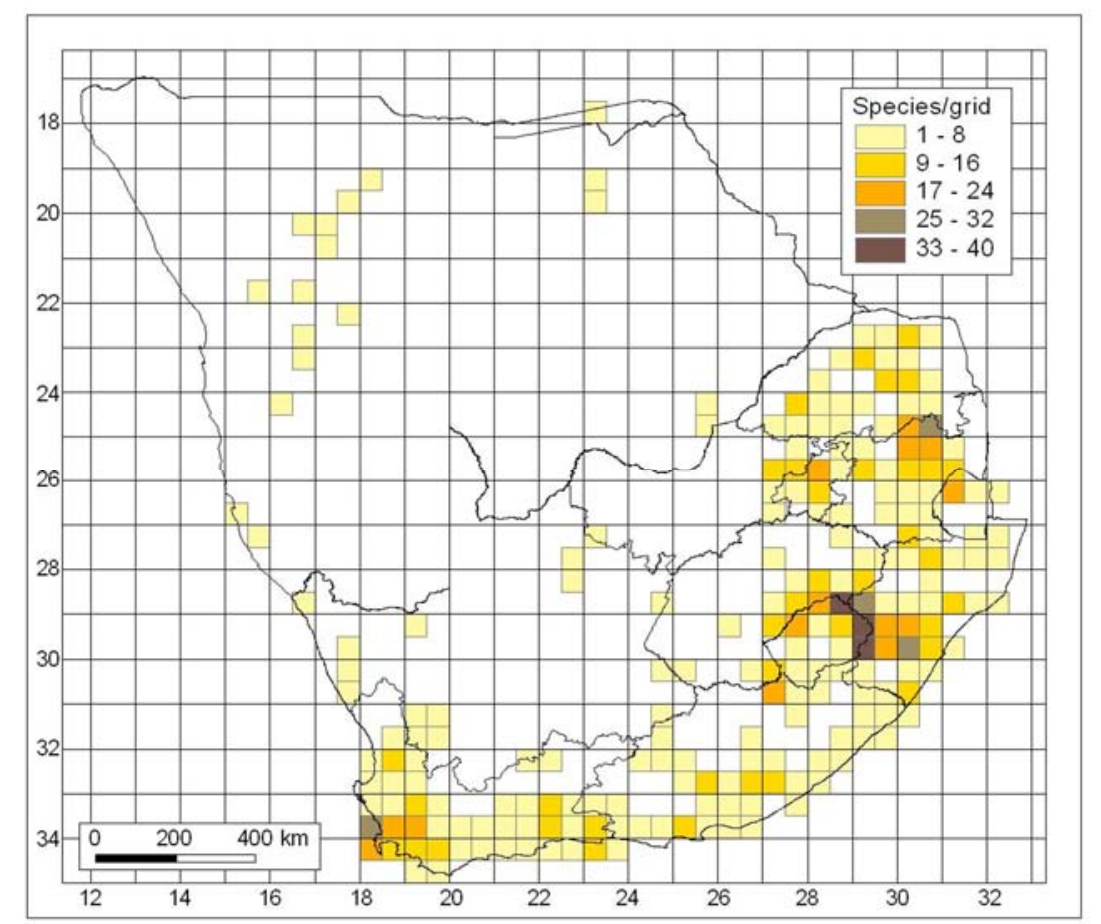

Figure 12. Geographical distribution of the Drakensberg Subelement 


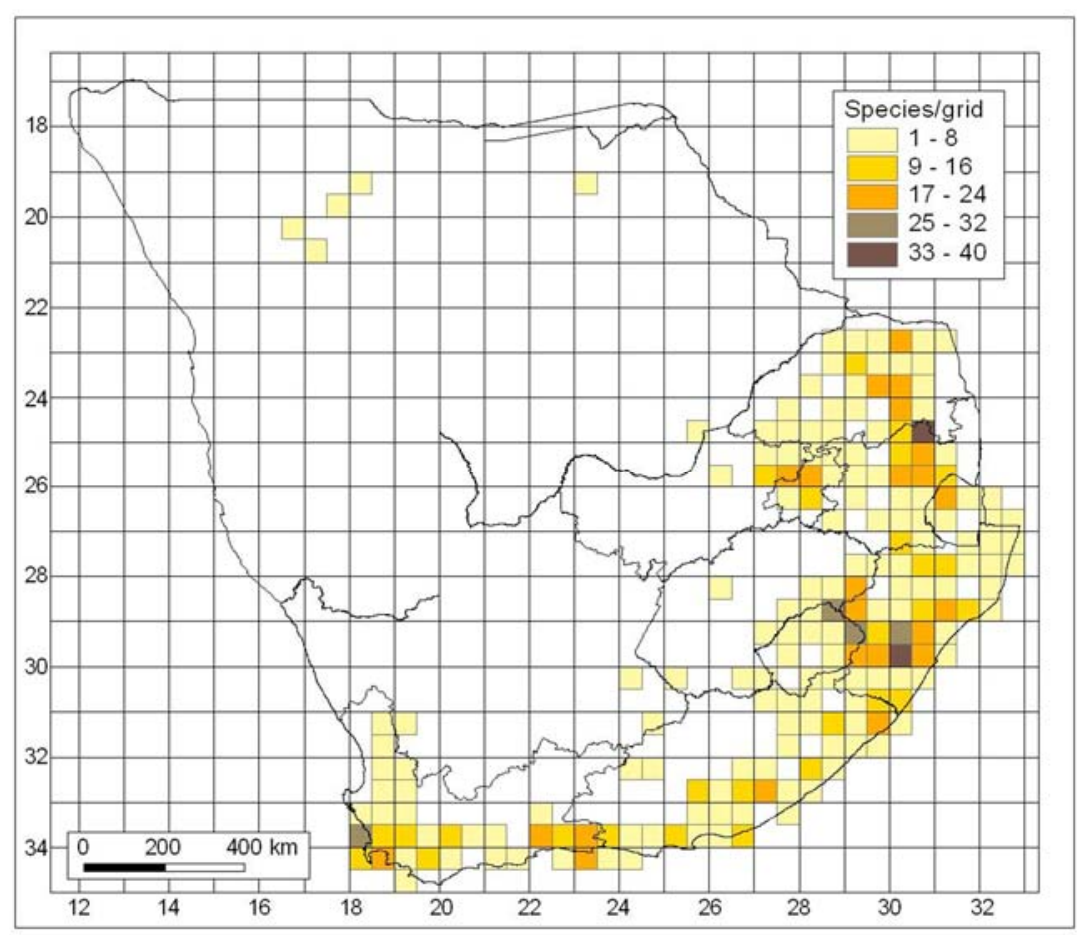

Figure 13. Geographical distribution of the Widespread Afromontane Subelement

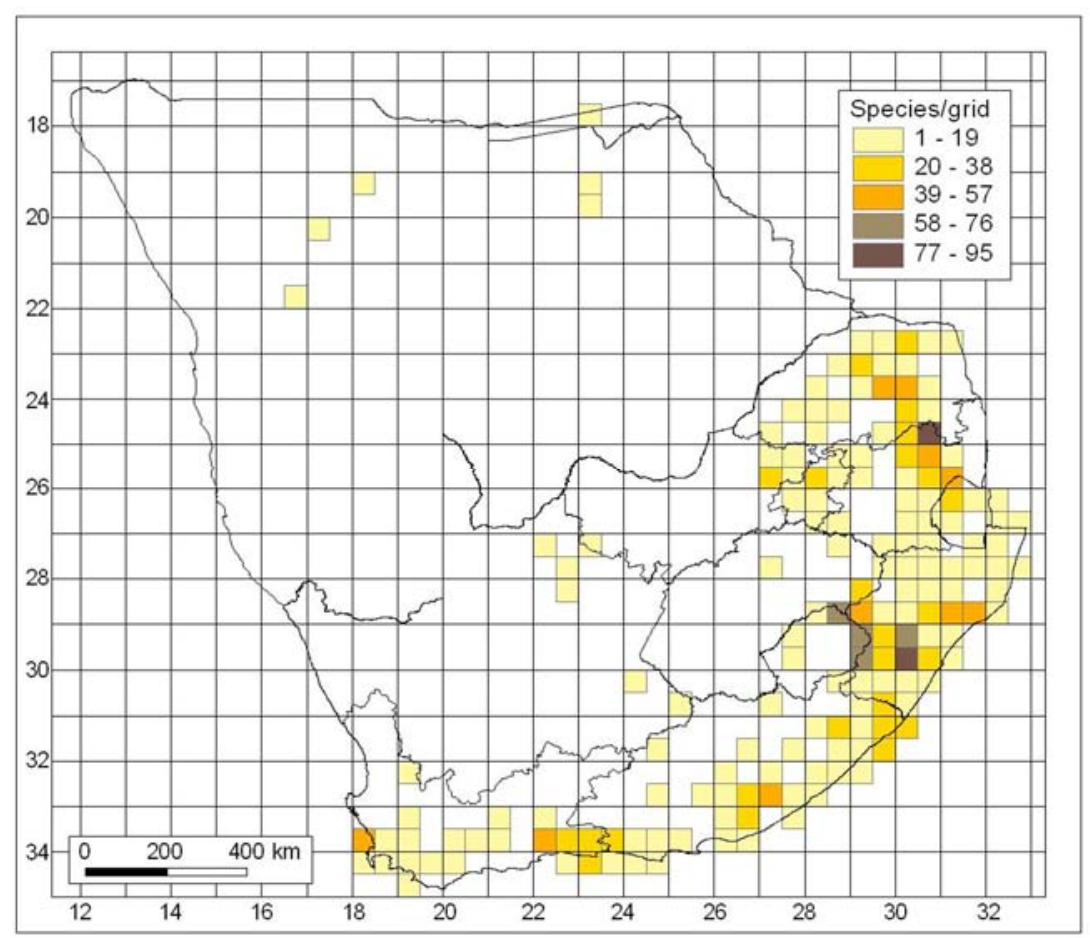

Figure 14. Geographical distribution of the Tropical Afromontane Subelement 


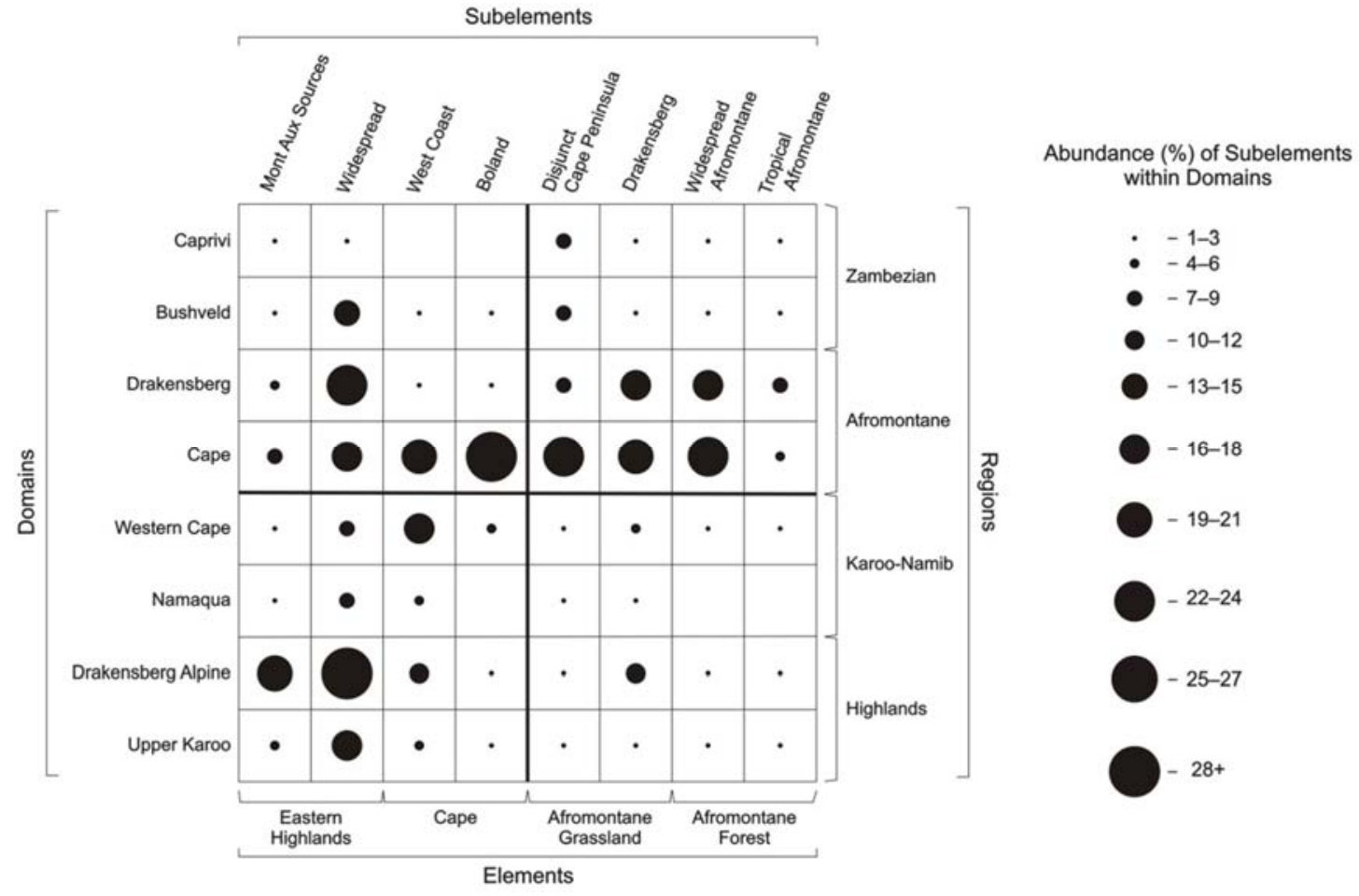

Figure 15. Summarised two-way table of the TWINSPAN 3+ classification. 